\title{
Port dynamics since 1965: Past patterns, current conditions and future directions
}

\author{
Peter J. Rimmer
}

\begin{abstract}
An examination is made of developments in port dynamics since 1965. Initially, this task is addressed by studying changes in past port patterns using a simple descriptive model to accommodate shifts induced by containerization. Over time these changes have led to the reversal of the concentration and centralization of port activities. Then consideration is given to the behavior of stakeholders active in the contemporary port scene by elaborating a bipolar globallocal analytical framework through an invocation of the hybrid concepts of glocalization and loglobalization. This analysis leads to an examination of emerging economies to gauge future trends in port dynamics following the dramatic emergence of China. Finally, there is a discussion of the need to go beyond inter-port competition to comprehend global production-distribution networks by exploring synergies between the supply chain and the total transport network to bring out parallels in the hub-and-spoke structure not only underpinning maritime activities but also air transport and telecommunications.
\end{abstract}

Keywords: globalization, inter-port competition, localization, port dynamics.

\section{Introduction}

In 1965 I received my doctorate for a study of New Zealand seaports (Rimmer, 1965). James Bird, the doyen of port geographers, had first discussed the topic with me at the annual meeting of the Institute of British Geographers three years earlier in Liverpool. Not only did Bird (1963, 1967,

Submission Date: 28/11/2005 Acceptance Date: 30/5/2007

*Hanjin Shipping Chair Professor of Global Logistics, Asia Pacific School of Logistics, Inha University, Incheon, Korea and Visiting Fellow, Division of Pacific and Asian History, Research School of Pacific and Asian Studies, the Australian National University, Canberra, ACT 022, Australia. E-mail: peter.rimmer@anu.edu.au 
1971) elaborate his conceptual framework for studying intra-port infrastructural developments and their relationship to the city in British ports at that meeting but also went on to test his 'Anyport' model in Australia, and attract further testing and elaboration by a legion of port geographers in other parts of the world (e.g. Hoyle, 1967, 1989; McCalla, 2004). ${ }^{1}$

I was not one of Bird's disciples, preferring to examine changes in inter-port dynamics through the further elaboration of Edward Taaffe, Richard Morrill and Peter Gould's (1963) model of transport development in underdeveloped countries. Colored by West African experience, this model focused upon the evolution of spatial patterns of port locations with the improvement of internal accessibility and the accompanying process of dominance ranking. However, the Taaffe, Morrill and Gould study did not pursue the development of seaports to its logical conclusion, as this topic was only of secondary importance to the expansion of the land transport network in underdeveloped countries as such. Indeed, in their preoccupation with the development of land communications and the emergence of high-priority "Main Streets" the authors neglected the development of maritime space. In an attempt to incorporate changes in both the maritime and land transport network I developed a simple descriptive model to serve as a yardstick for comparing the evolution of seaports.

It is now opportune to reflect upon the past forty years of port dynamics and raise a series of questions about the nature of inter-port competition, competitiveness and cooperation: how and why has the geographical impact of port dynamics changed between 1965 and 2005; how should the current players involved in port dynamics be conceptualized; and how is the pattern of port dynamics likely to evolve in the future.

In addressing these issues the initial emphasis is to progress beyond the descriptive model to highlight changes in inter-port patterns over the 40 years since 1965 induced by the further development and spread of containerization. The current roles of stakeholders are considered by going further than the bipolar global-local framework and invoking hybrid terms to better accommodate them. Then future trends in port dynamics are divined from the literature and assessed. A concluding comment reflects on the need to see inter-port competition in a wider context.

\section{Past patterns, 1965-2005}

My original descripive model was fashioned to account for the development of New Zealand seaports between 1883 and 1960 and underlined inter-port competition is not a new phenomenon (Fig. 1). Over that period the processes of penetration and hinterland capture, interconnection and concentration, and centralization transformed the original pattern of scattered ports along the coastline (Rimmer, 1967a). A deconcentration/decentralization phase was added when the model

\footnotetext{
${ }^{1}$ This interest has led to more economically focused studies of intra-port competition centered on the prevention of the market power of port providers and the promotion of specialization, flexible adaptation and innovation (Defillipi, 2004; De Langen and Pallis, 2005).
} 
was applied to spatial regularities in the evolution of Australian ports to accommodate the initial generation of purpose-built container ships requiring deeper water and dedicated facilities, typified by the development of Sydney's Port Botany (Rimmer, 1967b). With containerisation the network became the asset rather than ship per se (Yamada, 1997). ${ }^{2}$

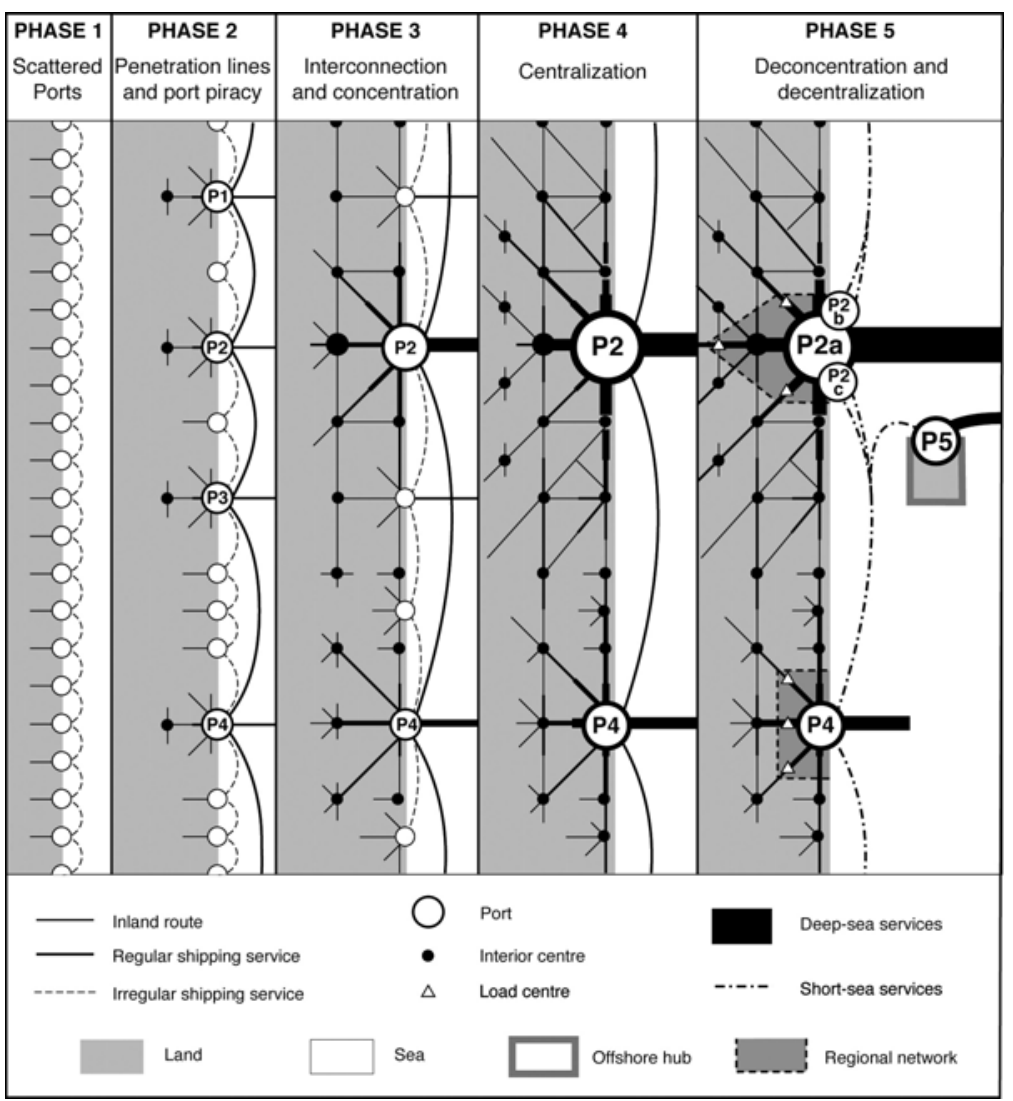

Source: Based on Rimmer, 1967b with additions derived from Notteboon and Rodrique, 2005.

Fig 1. The idealized sequence of port development

An examination of changes in the top-25 container ports at decadal intervals between 1970 and 2000 shows that marked changes in the rankings occurred over the thirty-year period (CI, 1970-2005). ${ }^{3}$ By 1980 London-Tilbury, Liverpool, Sydney and Halifax had been omitted from the rankings together with a host of short-sea 'pretenders' to container port glory (Table 1). Baltimore

\footnotetext{
${ }^{2}$ The ship still remains the asset in bulk shipping.

${ }^{3}$ There are some variations in throughput statistics as Containerisation International updates earlier figures in subsequent issues.
} 
and Melbourne had followed by 1990 and Le Havre had gone by 2000. Further Bordeaux, Jeddah and Honolulu had made their sole appearance in 1980, with Tacoma and Nagoya having their guest spots in 1990 .

Table 1

Top 25 ports in container traffic league

(thousand TEUs)

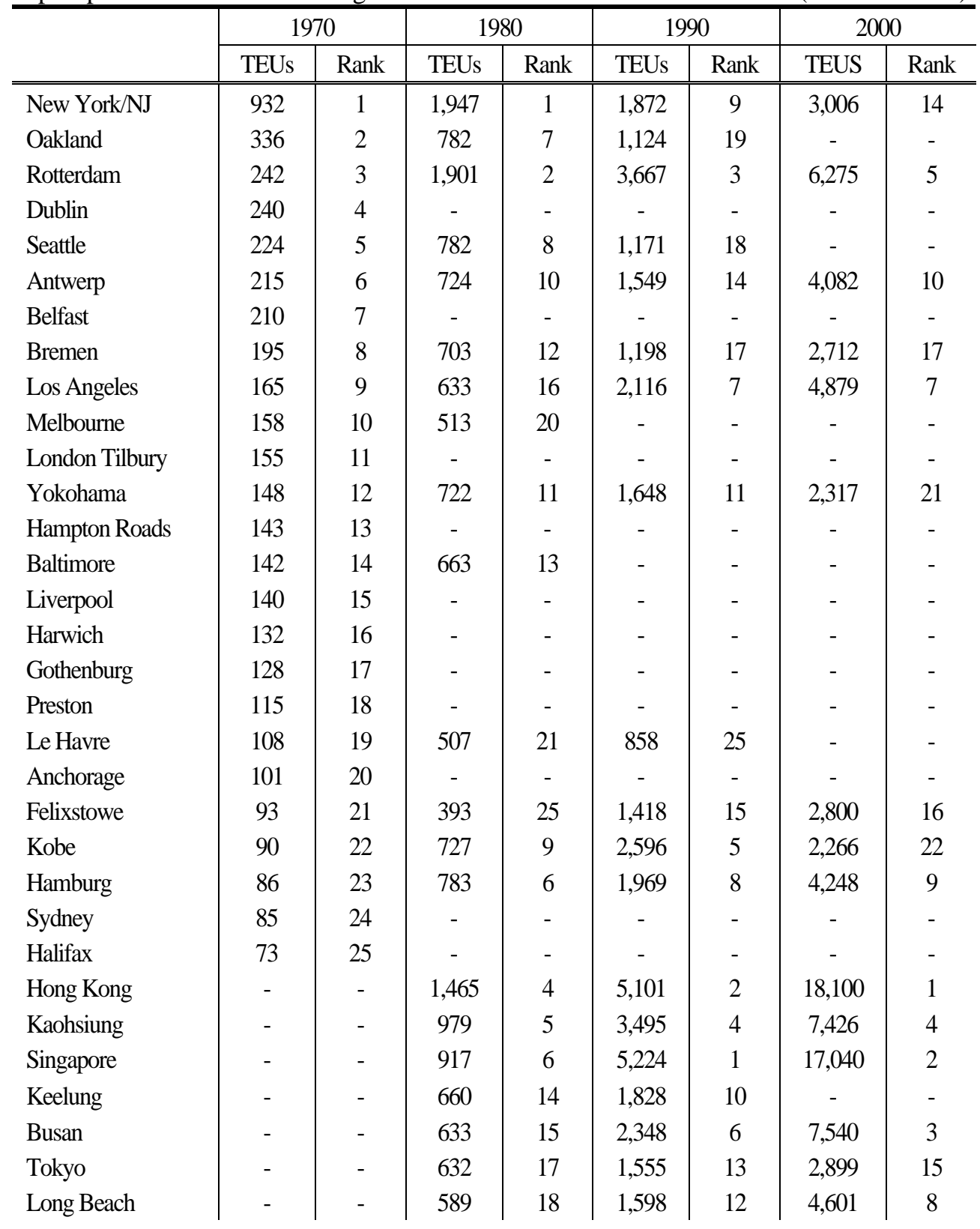




\begin{tabular}{l|c|c|c|c|c|c|c|c} 
Jeddah & - & - & 563 & 19 & - & - & - & - \\
Bordeaux & - & - & 453 & 22 & - & - & - & - \\
Honolulu & - & - & 441 & 23 & - & - & - & - \\
San Juan & - & - & 428 & 24 & 1,381 & 16 & 2,392 & 20 \\
Sydney & - & - & 365 & 25 & - & - & - & - \\
Manila & - & - & - & - & 1,039 & 20 & 2,867 & 15 \\
Bangkok & - & - & - & - & 1,018 & 21 & 2,195 & 23 \\
Tacoma & - & - & - & - & 938 & 22 & - & - \\
Dubai & - & - & - & - & 916 & 23 & 3,059 & 12 \\
Nagoya & - & - & - & - & 898 & 24 & - & - \\
Shanghai & - & - & - & - & - & - & 5,613 & 6 \\
Port Klang & - & - & - & - & - & - & 3,209 & 12 \\
GioiaTauro & - & - & - & - & - & - & 2,653 & 18 \\
Tanjung Priok & - & - & - & - & - & - & 2,476 & 19 \\
Yantian & - & - & - & - & - & - & 2,148 & 24 \\
Qingdao & - & - & - & - & - & - & 2,120 & 25 \\
\hline Solrce: CI(1970-2002)
\end{tabular}

Source: CI (1970-2002)

Conversely, only nine of the ports in 1970 maintained their positions in the top-25 at the beginning of each of the subsequent decades: New York/New Jersey and Los Angeles in North America, Rotterdam, Antwerp, Bremen/Bremerhaven, Hamburg and Felixstowe in Europe, and Yokohama and Kobe in Asia. Reflecting the subsequent industrlalization of Asia, the positions of the other ports were largely supplanted by the region's ports, notably Hong Kong, Kaohsiung, Singapore, Busan and Tokyo by 1980, Bangkok (Laem Chabang) and Dubai by 1990; and Shanghai, Port Klang. Tanjung Priok (Jakarta), Yantian and Qingdao by 2000. The only non-Asian ports bucking this trend were Long Beach since 1980 and Gioia Tauro in 2000.

Remarkably, these wide-ranging changes, accompanied by growth in the size of container ships and the increasing complexity of global modular production-distribution chains, required little modification to my original model. The adoption and spread of container technology initially reinforced the concentration/centralization phase and then accommodated generations of purposebuilt container ships in the deconcentration/deconcentration phase of the idealized sequence of port development (Hayuth, 1988). ${ }^{4}$ However, Theo Notteboom and Jean-Paul Rodrigue (2005) have suggested the addition of an 'offshore' hub to this fifth phase.

\subsection{The Offshore hub}

The addition was prompted by the appearance of seventeen offshore transshipment hubs before the end of the new millennium offering depths of at least $15 \mathrm{~m}$, room for expansion, lower labor costs, substantially carrier-owned terminals to handle transshipments, and scope for the

\footnotetext{
${ }^{4}$ At the time I used the word decentralization; decconcentration would have been more appropriate.
} 
subsequent development of logistics zones (SET, 2002). Seven offshore hubs are located in the southern Europe - Italy’s Cagliari, Gioia Tauro and Taranto, Malta Freeport, Portugals' Sines and Spain's Algeciras - but there are none in the northern European port range, though the prospect of one at Scapa Flow in the Orkney Islands, Scotland, is being investigated by Alfred Baird (2006).

Within Asia there are Colombo, Korea's Gwangyang Bay, the planned Kabil on Batam Island in Indonesia, Japan's Kitakyushu and Malaysia' Tanjong Pelapas. Although Tanjong Pelapas has captured significant business from Singapore, the latter port has refused to pursue destructive competition and chosen to counter the loss by marketing its key competencies to client ports in Asia and Europe.

None of the offshore transshipment hubs and their attendant feeder services are located in North America, as the gateways from Vancouver to Los Angeles on the west coast and New York/New Jersey to Houston on the east coast are origin-and-destination ports linked to internal markets within a continental intermodal landbridging system. Of the remaining hubs, Bahama's Freeport Brazil's Sepetiba and Panama's Manzanillo, the first named is the most strategically located with respect to North America.

\subsection{Is a sixth phase necessary?}

The minor surgery to my original descriptive model involving the addition of the offshore hub into the fifth phase of the model was deemed insufficient as Notteboom and Rodrique (2005) suggested a sixth phase of 'regionalization'. However, my argument is that the proposed changes can be accommodated within the fifth phase along with the offshore hub. What is regionalization but decentralization!

Notteboom and Rodrigue's (2005) rationale for adding a new phase is to accommodate Ross Robinson's (2002) recasting of the role of ports. Rather than describing ports as increasingly complex places, Robinson argues that they need to be seen as elements in the supply chains of multinational corporations. As shown in the new 'conceptual box', Robinson's (2002: 250) highlights that:

(i) the port is a third party service provider that intervenes in the supply chains of individual supply chains as a market-focused entity;

(ii) the port is one element among other firms in the import/export chain between producer and consumer designed to add and derive value;

(iii) the port offers superior value to shippers comprising markets segmented on the basis of value propositions of shippers; and

(iv) the port competes with other ports as a market-focused firm or entity embedded in the constellation of chains of supply focused on the port (Fig. 2)

In short, Robinson's (2002: 250) mantra is that 'chains compete not individual ports'. 


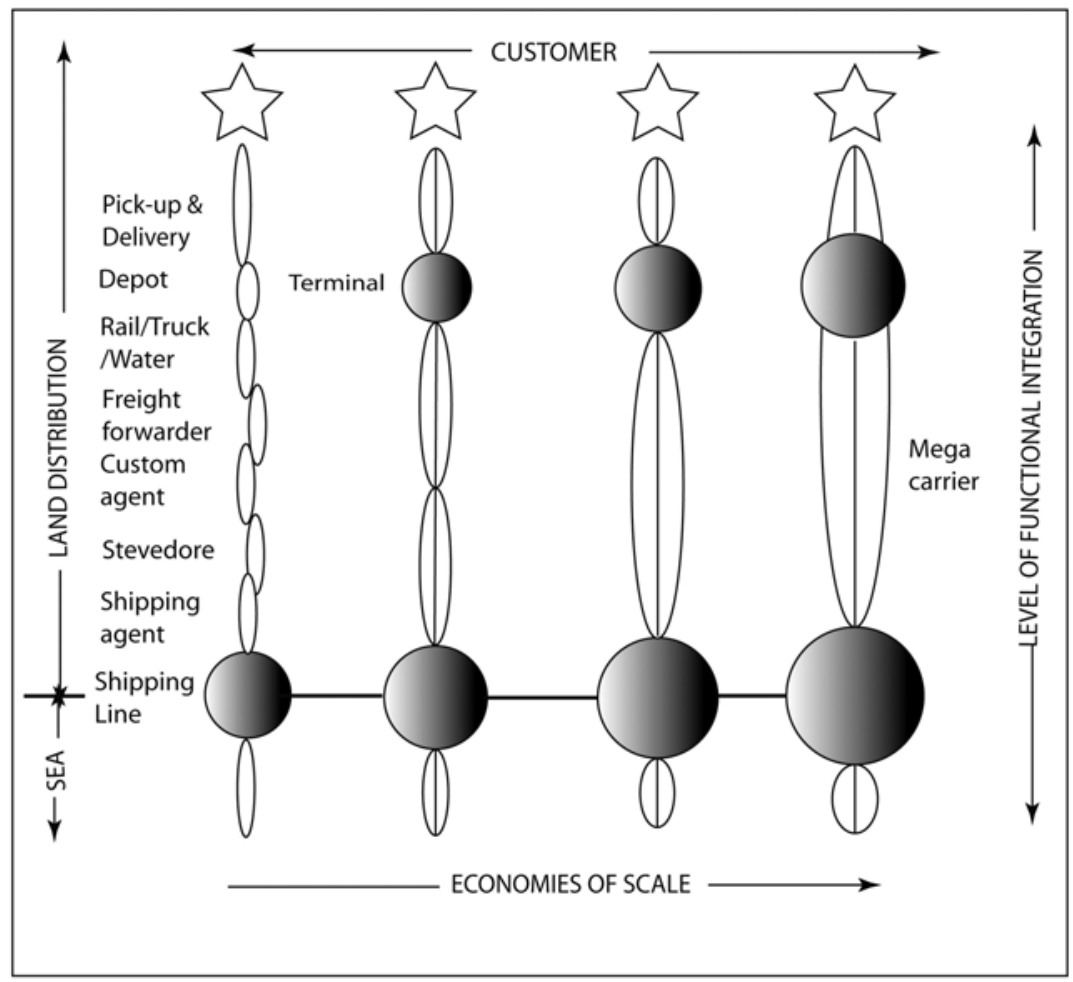

Fig 2. The conceptual box showing Robinson's (2002) propositions on the role of ports in the value chain.

In suggesting a new phase, Notteboom and Rodrique make much use of Robinson's (2002) diagram that encapsulates the progressive collapse of separate maritime and land-based firms and functions into an integrated, corporate, intermodal network providing economies of scale in distribution. The only significant addition to the diagram introduced by Notteboom and Rodrique (2005) is the interposition of the 'terminal', which comes under the control of the megacarrier (Fig. 3). This 'inland' terminal is a cargo bundling point, consolidation and deconsolidation center, and logistics zone. After identifying the inland terminal and the freight corridors as the twin 'cornerstones' of the new phase, the authors proceed to recognize a freight distribution center. ${ }^{5}$ Located near consumer markets, the freight distribution center is where the logistics service providers (LSPs) handle the onforwarding tasks outsourced by manufacturers to create significant value in the supply chain. These additions reflect specific developments in Europe, North America and, possibly, Asia.

${ }^{5}$ The inland terminal is also referred to as an inland container deport (ICD) and dry terminal. 


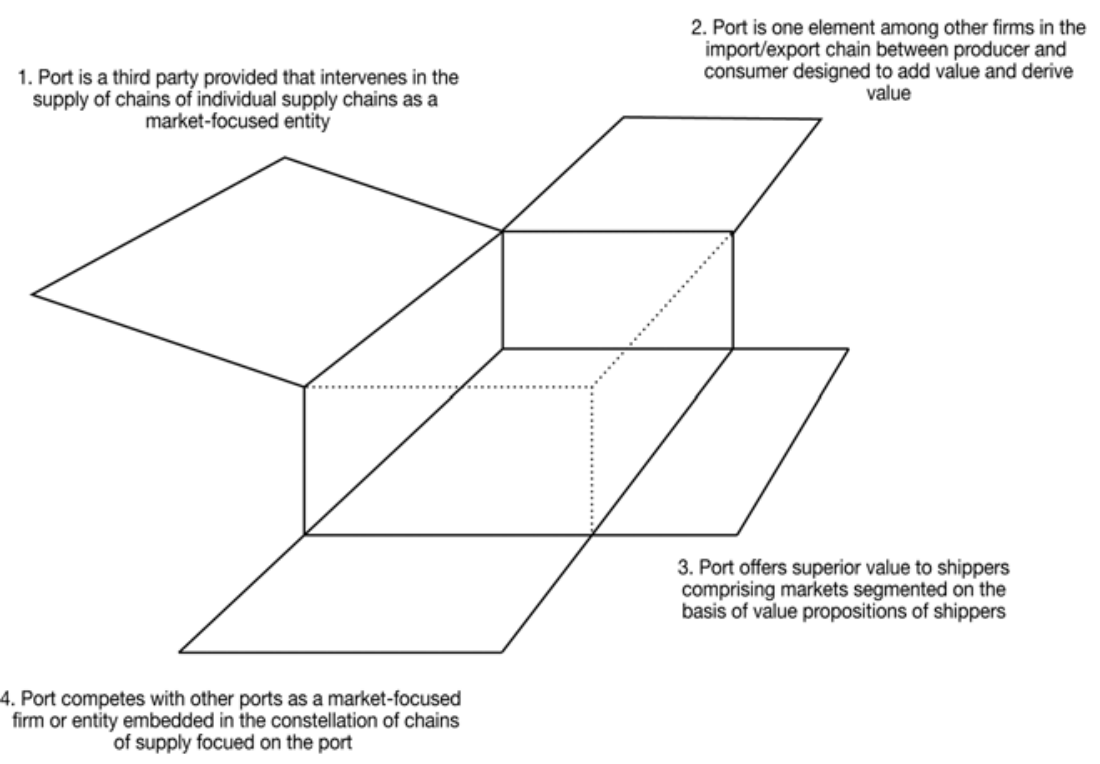

Figure 3. The original Robinson (2004) model with amendments by Notteboom and Rodrique (2005)

In northem Europe the inland terminals stem from intensified competition between the top 10 well-established port undertakings (operators and port authorities) listed in Table 2 that are seeking to generate added value in supply chains (ESPO, 2005; Notteboom, 2005). This competition stems from the overlay and intersection of hinterlands in northern Europe and the Mediterranean. However, the competitive cue stems from the Low Countries where there are immediate and direct competitive pressures between terminals in Rotterdam, Antwerp and Zeebrugge, a smaller port taking advantage of some of the inefficiencies of larger ports. According to Ocean Shipping Consultants Ltd. (OSC, 2005), price, capacity and service issues between these terminals not only sets the market's competitive tone but attracts many researchers such as Adolf $\mathrm{Ng}$ (2004) seeking to model inter-port competition. ${ }^{6}$ These ports are also competing with terminals in Hamburg and Bremen/Bremerhaven for the German hinterland and eastern and central Europe, which are resulting in terminal operators operating European Distribution Centers making strategic

\footnotetext{
${ }^{6}$ Adolf Ng used the following variable in his model: waiting/transit time in port; locational efficiency (UK/Ireland); locational efficiency (Scan-Baltic); locational; efficiency (IberianPen); cause of delays during transshipment; records of damage during stevedoring; customs procedures; port authority policy \& regulation; accession to port; quality of port superstructure; IT \& Advanced technology; dedicated terminals; supporting industries; other services (e.g. pilotage), availability of professional personnel in port, preference of shipping line clients/shippers, personal contacts/relations and efforts of marketing by port authority. His survey of the perceptions of shippers found that Rotterdam has superior location attributes but ranked among the bottom three ports in northern Europe in performance.
} 
connections with the development of smaller inland terminals offering rail/inland waterways such as Duisburg, Dusseldorf, Regensburg and Vienna, which are becoming key centers in the automobile production (Podevins, 2005). Further, terminals in France and the United Kingdom are rivals for the same business in transshipments.

Table 2

Top 10 north European ports

(thousand TEUs)

\begin{tabular}{l|c|c|c|c|c|c|c|c|c|c}
\hline & \multicolumn{2}{|c|}{1970} & \multicolumn{2}{c|}{1980} & \multicolumn{2}{c|}{1990} & \multicolumn{2}{c|}{2000} & \multicolumn{2}{c}{2004} \\
\hline \hline Rotterdam & 242 & 1 & 1,901 & 1 & 3,667 & 1 & 6,275 & 1 & 8,281 & 1 \\
Hamburg & - & - & 783 & 2 & 1,969 & 2 & 4,248 & 2 & 7,003 & 2 \\
Antwerp & 216 & 2 & 724 & 3 & 1,549 & 3 & 4,082 & 3 & 6,064 & 3 \\
Bremen & 194 & 4 & 703 & 4 & 1,198 & 5 & 2,712 & 4 & 3,448 & 4 \\
Felixstowe & - & - & 246 & 9 & 1,436 & 4 & 2,853 & 6 & 2,700 & 5 \\
Le Havre & - & - & 507 & 5 & 858 & 6 & 1,465 & 5 & 2,132 & 6 \\
Southampton & - & - & 362 & 7 & 345 & 9 & 1,062 & 7 & 1,441 & 7 \\
Zeebrugge & - & - & - & - & 342 & 10 & 965 & 8 & 1,198 & 8 \\
St. Petersburg & - & - & - & - & - & - & - & - & 773 & 9 \\
Gothenburg & 128 & 10 & - & - & 352 & 8 & 685 & 9 & 731 & 10 \\
Bordeaux & - & - & 453 & 6 & - & - & - & - & - & - \\
Tilbury & 155 & 6 & 272 & 8 & 363 & 7 & - & - & - & - \\
Greenore & - & - & 176 & 10 & - & - & - & - & - & - \\
Belfast & 210 & 3 & - & - & - & - & - & - & - & - \\
Tilbury & 155 & 5 & - & - & - & - & - & - & - & - \\
Larne & 147 & 7 & - & - & - & - & - & - & - & - \\
Liverpool & 140 & 8 & - & - & - & - & 540 & 10 & - & - \\
Harwich & 140 & 9 & - & - & - & - & - & - & - & - \\
\hline
\end{tabular}

Source: CI (1970-2006).

In North America the inland terminal additions reminiscent of Europe’s articulation points, freight corridors, centers and flows are most evident in the distribution network developed by the Port of New York/New Jersey beyond its jurisdictional territory. This network features inland terminals serving freight clusters stretching from Boston to Washington via rail or barge not only to handle intermodal movements seamlessly but to ease congested terminal space and meet environmental regulations in a cost-efficient manner (Hall, 2003; Rodrigue, 2004; Rodrigue and Hesse, forthcoming). The other positive feature is the Alameda freight corridor connecting Ports of Los Angeles and Long Beach to the intermodal system, which has enabled the San Pedro Ports to cope with the rise of Northeast and Southeast Asia as major export-manufacturing regions. Also a FAST corridor has been designated in the Puget Sound region. Among the top 10 ports in North America listed in Table 3, there is competition within port ranges (a) across international borders 
(e.g. Seattle v. Vancouver), ${ }^{7}$ (b) between those in close proximity offering similar services to overlapping hinterlands for the same business (e.g. Seattle v. Tacoma), (c) between ports with similar hinterlands and/or functions (e.g. Seattle/Tacoma v. Los Angeles/Long Beach for midcontinental or eastern seaboard cargoes); and between port ranges (e.g. Seattle/Tacoma v. New York/New Jersey for cargoes from Southeast Asia ports roughly equidistant from both) (Goss, 1990; Barzadukas et al., 2000). Highly dependent on imports from China, the major retailer WalMart, for example, was able to destroy any notion of a captive hinterland by moving its operations from congested West Coast ports clogged with imports from Asia to Houston (Hensel, 2004).

Table 3

Top 10 north American ports

(thousand TEUs)

\begin{tabular}{l|c|c|c|c|c|c|c|c|c|c}
\hline Port & \multicolumn{2}{|c|}{1970} & \multicolumn{2}{c|}{1980} & \multicolumn{2}{c|}{1990} & \multicolumn{2}{c|}{2000} & \multicolumn{2}{c}{2004} \\
\hline \hline Los Angeles & 165 & 3 & 633 & 5 & 2,116 & 1 & 4,879 & 1 & 7,321 & 1 \\
Long Beach & 49 & 8 & 589 & 6 & 1,598 & 3 & 4,601 & 2 & 5,780 & 2 \\
New York/NJ & 932 & 1 & 1,947 & 1 & 1,872 & 2 & 3,006 & 3 & 4,478 & 3 \\
Oakland & 336 & 2 & 782 & 2 & 1,124 & 5 & 1,776 & 4 & 2,043 & 4 \\
Tacoma & - & - & - & - & 937 & 6 & 1,376 & 7 & 1,864 & 5 \\
Charleston & - & - & 340 & 9 & 807 & 7 & 1,633 & 5 & 1,809 & 6 \\
Virginia & 143 & 4 & 353 & 8 & - & - & 1,348 & 8 & 1,798 & 7 \\
Seattle & - & - & 782 & 3 & 1,171 & 4 & 1,488 & 6 & 1,776 & 8 \\
Vancouver & - & - & - & - & - & - & 1,163 & 9 & 1,665 & 9 \\
Savannah & - & - & - & - & - & - & - & - & 1,622 & 10 \\
Houston & - & - & - & - & - & - & 1,074 & 10 & - & - \\
Baltimore & - & - & 663 & 4 & - & - & - & - & - & - \\
Hampton Rds & - & - & - & - & 789 & 8 & - & - & - & - \\
Honolulu & - & - & 441 & 7 & 605 & 9 & - & - & - & - \\
Montreal & 67 & 7 & 300 & 10 & 588 & 10 & - & - & - & - \\
Philadelphia & 120 & 5 & - & - & - & - & - & - & - & - \\
Anchorage & 101 & 6 & - & - & - & - & - & - & - & - \\
Miami & 48 & 9 & - & - & - & - & - & - & - & - \\
Boston & 26 & 10 & - & - & - & - & - & - & - & - \\
\hline
\end{tabular}

Source: CI (1970-2006).

In Asia land-based regionalization has been limited by the heavy reliance on feeder shipping centered upon the key hubs of Singapore, Hong Kong, Kaohsiung, Busan and Kobe elaborated by Ross Robinson (1998) and the author (Rimmer, 1997, 1998). Since 1980 Wei Yim Yap and

\footnotetext{
${ }^{7}$ Vancouver Port Authority has a US\$1.6 billion expansion plan which will triple existing capacity to 5.3 million TEUs (Delattre, 2005).
} 
Jasmine Lim (2006) argue that Hong Kong and Busan have been the main beneficiaries of interport competition among the top 10 ports (Table 4). At one stage Hong Kong served China south of the Yangtse and Busan usurped the position of Japanese ports by offering better cost-quality combinations to serve north China and parts of Japan. Indeed, China is the only likely area of Asia where terminal development is likely to occur on a European or American scale, particularly as there has been a retreat from inland transport networks serving the agricultural interior in Southeast Asia to the mega-urban manufacturing centers on or near the coast (Dick and Rimmer, 2003). As yet the superstructure for its realization in China is centered upon the three competitive ports of Hong Kong and Yantian in the Pearl River Delta and Shanghai in the Lower Yangtse, which are ranked ahead of Bohai Rim ports (Wang and Slack, 2000; Song and Yeo, 2004). While several international terminal operators have staked out the ports in China attracting direct calls from major shipping lines, the country still lacks the panoply of corridors and inland terminals (Song, 2002). The improvement of ports as key links in the logistics chain is prompting heavy investment by China maritime and land-based transport infrastructure to handle cargoes currently transshipped (Cheung et al., 2003). ${ }^{8}$ As outlined by Jung-Yoon Lee and Jean-Paul Rodrigue (2006), the marked 'China effect' is, for instance, resulting in a shift away from export gateways such as Busan to west coast ports being integrated into Yellow Sea Rim supply chains (OECD, 2004: 41-45).

Table 4

Top 10 far east and Asian ports

(thousand TEUs)

\begin{tabular}{l|c|c|c|c|c|c|c|c|c|c}
\hline & \multicolumn{2}{|c|}{1970} & \multicolumn{2}{|c|}{1980} & \multicolumn{2}{c|}{1990} & \multicolumn{2}{c|}{2000} & \multicolumn{2}{c}{2004} \\
\hline \hline Hong Kong & 36 & 5 & 1,465 & 1 & 5,101 & 2 & 18,100 & 1 & 21,984 & 1 \\
Singapore & - & - & 917 & 3 & 5,224 & 1 & 17,040 & 2 & 20,600 & 2 \\
Shanghai & - & - & - & - & - & - & 5,613 & 5 & 14,557 & 3 \\
Shenzhen & - & - & - & - & - & - & - & - & 13,650 & 4 \\
Kaohsiung & - & - & 979 & 2 & 3,495 & 3 & 7,426 & 4 & 9,710 & 4 \\
Busan & - & - & 633 & 7 & 2,348 & 5 & 7,540 & 3 & 11,430 & 5 \\
Port Klang & - & - & - & - & - & - & 3,207 & 6 & 5,244 & 7 \\
Qingdao & - & - & - & - & - & - & - & - & 5,140 & 8 \\
Tg Pelapas & - & - & - & - & - & - & - & - & 4,020 & 9 \\
Ningbo & - & - & - & - & - & - & - & - & 4,006 & 10 \\
Tokyo & 54 & 3 & 632 & 8 & 1,555 & 8 & 2,899 & 7 & - & - \\
Tanjung Priok & - & - & - & - & - & - & 2,476 & 9 & - & - \\
Yokohama & 148 & 1 & 722 & 5 & 1,648 & 7 & 2,317 & 10 & - & - \\
Manila & - & - & 256 & 9 & 1,039 & 9 & 2,867 & 8 & - & - \\
Kobe & 90 & 2 & 727 & 4 & 2,596 & 4 & - & - & - & - \\
Keelung & - & - & 660 & 6 & 1,828 & 6 & - & - & - & - \\
Bangkok & - & - & - & - & 1,018 & 10 & - & - & - & -
\end{tabular}

${ }^{8}$ The port of Shanghai is spending US\$6.9 billion to achieve an annual capacity of 25 million TEUs by 2010 (USDOT, 2005: 28). 


\begin{tabular}{l|c|c|c|c|c|c|c|c|c|c} 
Osaka & - & - & 254 & 10 & - & - & - & - & - & - \\
Nagoya & 45 & 4 & - & - & - & - & - & - & - & - \\
Osaka & 30 & 6 & - & - & - & - & - & - & - & - \\
Yokkaichi & 12 & 7 & - & - & - & - & - & - & - & - \\
Singapore & 6 & 8 & - & - & - & - & - & - & - & - \\
Shimizu & 4 & 9 & - & - & - & - & - & - & - & - \\
\hline
\end{tabular}

Source: CI (1970-2006).

These regional developments do not need a special phase as they can be accommodated by inserting the elements suggested by Notteboom and Rodrique (2005) — regional load centers, and their diiscontinuous hinrterlands, and the identication of an axial corridor to the inherited transport network - into the fifth phase of my model (Fig. 1). If we become concerned with regionalization per se the focus will return to Taaffe, Morril and Gould's (1963) preoccupation with the land-based network, which prompted the development of a model that accommodated the development of maritime space in the first place. Rather then pursue Notteboom and Rodrigue's suggestion that these developments require a distinctive port governance policy, it is time to part company with the authors and return to fundamentals with a view to providing port administrators and container terminal operators with fresh insights into policy making and formulating strategic decisions. Perhaps the initial task is to resolve Geraldo De Souza Jr., Anthony Beresford and Stephen Pettit's (2003) dilemma as to whether liner shipping companies (LSCs) and terminal operating companies (TOCs) are international or global by clarifying the global-local framework. ${ }^{9}$ This framework is continually being invoked to comprehend current conditions in port dynamics — global convergence at sea and local divergence on land stemming from geographical, economic, infrastructural and institutional variations (McCalla et al., 2004).

\section{Current conditions}

A prime reason for invoking the global-local framework is that competition between ports within the same country raises the issue as to who is paying and benefiting from the competition. ${ }^{10}$ Since ports are but one link in the supply chain the real beneficiaries of port efficiency accrue to producers at the origin of the supply chain, notably multinational corporations, and consumers at the final destination because they both enjoy lower cost trade (Goss, 1990; Haynes et al., 1997). As corporations operate in global arenas and public sector officials (PSOs) at the local level there is often a disconnection between the two. Many local public sector officials do not comprehend the full ramifications of freight moving through their jurisdictions and have yet to fully involve the multinational corporations in the planning process. Conversely, the multinational corporations do

\footnotetext{
9Slack and Frémont (2005) argue that terminal operating companies have moved from being 'local' to 'global'.

${ }^{10}$ In the global-local framework the local has to be defined. Regional, national and supra-regional are all 'local'.
} 
not have the requisite personnel, time and resources to consider local decisions influencing their world-spanning supply chains.

The issue needs to be unpacked further as classifying everything as either 'global' or 'local' has its shortcomings (i.e. multinational corporations and shipping lines are global and public sector officials and port operators are local). In particular, the dominant geographical scale of the 'local' has to be specified in discussing each particular issue (i.e. supra-national national, regional subregional are all 'local'). One way out of the dilemma is to recognize that some stakeholders can be simultaneously 'global' and 'local'. This involves invoking the hybrid concepts of 'glocalization' and 'lo-globalization'.

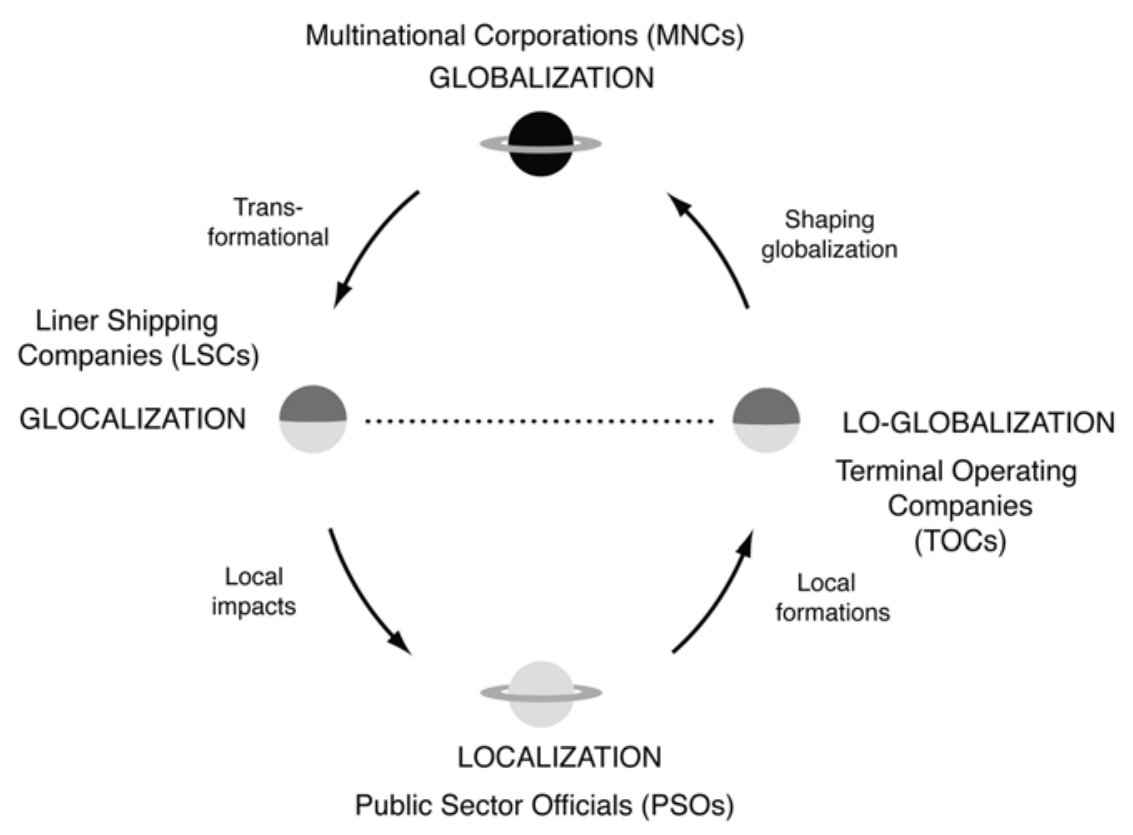

Shipping Corporations/Alliances

Source: Based on Rimmer (2004)

Fig 4. The expanded global-local framework. 
Table 5

Strategies of stakeholders

\begin{tabular}{|c|c|}
\hline $\begin{array}{l}\text { MULTINATIONAL CORPORATION (MNC) } \\
\text { Global production systems } \\
\text { Shift to flexible organization offering economies of } \\
\text { scope not scale (i.e. Fordism to post-Fordism) } \\
\text { Outsourcing of component products, value added } \\
\text { logistics and transport warehousing and distribution }\end{array}$ & $\begin{array}{l}\text { PORT TERMINAL OPERATORS (PTO) } \\
\text { International terminal networks } \\
\text { Supply Chain functions }\end{array}$ \\
\hline $\begin{array}{l}\text { LINER SHIPPING CORPORATIONS (LSC) } \\
\text { Changing market environment } \\
\text { Instability in liner shipping } \\
\text { Scale increase in vessel size } \\
\text { Cooperation, mergers and acquisitions } \\
\text { Landside logistics } \\
\text { Change in liner shipping network design } \\
\text { Limits to hub-and-spoke principle } \\
\text { Global coverage— alliances } \\
\text { Connections to local inland transport system }\end{array}$ & $\begin{array}{l}\text { PUBLIC SERVICE OFFICIALS (PSO) } \\
\text { Reassessment of port management strategies } \\
\text { To accommodate the large port clients } \\
\text { To secure investments } \\
\text { To deal with increased port competition } \\
\text { To deal with possible drawbacks of load centering } \\
\text { Instability in the port industry } \\
\text { The unfair distribution of costs and benefits of } \\
\text { load centering } \\
\text { Diseconomies of scale in load centers } \\
\text { Gaining competitive advantage in post-Fordian } \\
\text { era } \\
\text { Inimitable and durable core competencies } \\
\text { The role of port authorities } \\
\text { value-added logistics } \\
\text { development of information systems } \\
\text { as active participants in the planning and or } \\
\text { implementation of new intermodal) transport } \\
\text { services } \\
\text { port networking } \\
\text { port networking with satellite locations } \\
\text { a port networking strategy focused on inland } \\
\text { locations } \\
\text { port networking with overseas ports } \\
\text { port networking among neigtboring ports }\end{array}$ \\
\hline
\end{tabular}

Source: Notteboom and Winkelmans, 2001; Notteboom, 2004.

These additional concepts allow the recasting of the roles of stakeholders in port dynamics 
(Fig. 4). ${ }^{11}$ Multinational corporations (MNCs) represent the universalizing and homogenization processes associated with globalization (Table 5). Within the context of a change from manufacturer-led to retailer-led supply chain (i.e. from 'push' to 'pull' supply chain economics epitomized by General Motors and Wal-Mart respectively), the emphasis is on the development of a strong brand name and the outsourcing of production components, logistics manipulations transport, warehousing and distribution (Euro-CASE, 2000; Notteboom and Winkelmans, 2001: 7; Lai et al., 2004; ESPO, 2005: 16). Their need to move containers is communicated to liner shipping companies (Notteboom, 2004), who have a transformational impact on ports through the process of glocalization. In turn, the local impacts on the community stemming from the port through intermodality demand a response from public service officials (PSOs). Far from being mere pawns in the globalization process, public service officials are able to change the efficiency/effectiveness of the local formation by either (i) increasing their flexibility through changing operational controls to affect performance (i.e. funding and cost recovery); (ii) commercialization through the government changing macro-economic controls to alter their conduct (i.e. corporatization); or (iii) privatization by changing the ownership of assets (i.e. denationalization) (Rimmer and Chang, 2005; Tongzon and Wu, 2005). The last approach leads to lo-globalization as the public service officials can enter agreements with the private sector operating terminal operating companies who, in turn, reshape the nature globalization by offering multinational corporations a different set of options.

The task ahead is to develop and test various propositions regarding the key players in port dynamics. Do the multinational corporations (shippers/receivers) play the key role in port choice within their supply chains, as suggested by Robinson (2002) and Tiwari, Itoh and Doi (2003), or it is the liner shipping corporations as proposed by Slack (1999)? Are the public service officials or terminal operating companies able to offer the lowest price for a particular service level to be chosen as the port-of-call? What factors in Table 6 are critical in enhancing a port's competitiveness? ${ }^{12}$ What factors make some seaports better at anticipating infrastructural needs and implementing their plans? What role do sea and hinterland distances play? Is there any agreement on measuring the efficiency of a port as link in the logistics chain? ${ }^{13}$

\footnotetext{
${ }^{11}$ Maloni and Jackson (2005) identify both operational stakeholders who are involved in one stage of container distribution including landside (shippers, railroads, drayage carriers and ocean carrier intermediaries), port (leadership, terminal operators and labor) and waterside resources (ocean transportation intermediaries); and strategic stakeholders, including government and the local community as they significantly affected capacity and stand to suffer from the resolution of capacity issues.

${ }^{12}$ Gustaff De Monie (1987) has reported the difficulties of measuring ports productivity due to: the sheer number of parameters involved, the lack-of-up-to-date, factual and reliable data, collected in an accepted manner and available for dissemination; the absence of generally agreed and acceptable definitions; the profound influence of local factors on the data obtained; and the divergent interpretation given by various interests to identical results (cited by USDOT, 2005: 8).

${ }^{13}$ Khalid Bichou and Richard Gray (2004) report that measures "of port efficiency or performance indicators use a diverse range of techniques for assessment and analysis, but although many analytical tools and instruments exist, a problem arises when one tries to apply them to a range of ports and terminals. Ports are very dissimilar and even within a single port the current or potential activities can be broad in scope and nature, so that the choice of an appropriate tool is difficult. Organizational dissimilarity constitutes a serious limitation to enquiry, not only concerning what to measure but how to measure. Furthermore the concept of efficiency is vague and proves difficult
} 
Table 6

Factors affecting port performance, port cargo volume, port efficiency and port choice

\begin{tabular}{l|l|l}
\hline \multicolumn{1}{c|}{ Port cargo volume } & \multicolumn{1}{|c}{ Port efficiency } & Port choice \\
\hline \hline $\begin{array}{l}\text { Type of cargo handled by the port } \\
\text { (specialization) }\end{array}$ & $\begin{array}{l}\text { Labor efficiency (cargo moved port unit } \\
\text { of labor) }\end{array}$ & Cost \\
\hline $\begin{array}{l}\text { Location of ports relative to shippers' } \\
\text { markets (regional demands) }\end{array}$ & $\begin{array}{l}\text { Land use efficiency (cargo storage per unit } \\
\text { of land) }\end{array}$ & Time differences \\
\hline $\begin{array}{l}\text { Price of port services relative to } \\
\text { shippers' alternative ports }\end{array}$ & Waterside access limitations & Service quality \\
\hline Waterside access limitation & Capacity of port road and rail competition & \\
\hline Carrier investment in port infrastructure & Inland transportation availability & \\
\hline Quality of port services & Cargo handling capability & \\
\hline $\begin{array}{l}\text { Business realignment to increasing } \\
\text { purchasing power }\end{array}$ & & \\
\hline $\begin{array}{l}\text { Availability of national government } \\
\text { subsidies }\end{array}$ & & \\
\hline
\end{tabular}

Source: USDOT, 2005.

\section{Future directions}

If you focus on the premise that "inland distribution is becoming a very important dimension of the globalization/maritime distribution/freight distribution paradigm” the inevitable focus will be on continental areas capable of hosting the regionalization phase (Notteboom and Rodrigue, 2005). There is always a danger with the emphasis on discrete developments in the triad — Europe, North America and Asia - that we focus on the concerns of the major research communities and lose sight of the wider picture. ${ }^{14}$

If the focus is shifted to the oceanic economy, such as the Trans-Pacific, a new set of network dimensions and priorities emerge (Dick and Rimmer, 1993). Indeed, if the concern is to be the importance of ports in global supply chains this may be a more appropriate spatial scale of analysis. Significantly, Hokey Min and Zijian Guo (2005) even go beyond the Trans-Pacific oceanic economy and incorporate east coast ports in North America in their concern with using a cooperative competition strategy distilled from game theory in determining the optimal location of East Asian hub-seaports within the global supply chain.

Of course, the oceanic economies, in turn, are part of the global hub and spoke system, which is perhaps where we should have started with at the beginning. The system comprises hubs on the

to apply in the typical port organization extending across production, trading and service industries”.

${ }^{14}$ For example, Brian Hoyle and Jacques Charlier (1995) have offered an East Asia case study of inter-port competition. The study illustrates the development of an integrated port hierarchy and the current problems of interport competition. 
world-spanning Main Street linking Europe, Asia and North America with north-south cul-de-sacs in Africa. Australasia and Central and South America. Assessing a port's role and market share within such a network means that, according to Simme Veldman and Ewout Buckmann (2003), part of the network has to be singled out without loss of consistency. A finer meshed framework than presented here would be suitable for examining ship assignments with hub and spoke constraints (Mourao, Pato and Paixao, 2001).

A global focus is also important if we are to anticipate where the next areas of container development and inter-port competition are to occur. With no expected reversal of outsourcing, China, with only $20 \%$ of its cargoes containerized, is inevitably seen as continuing to be the pacesetter with the anticipated growth of gateway hub ports. Not only does the country figure prominently in forecasts for the throughput of competitive European and North American ports but also China has important spillover effects on neighboring ports in Asia. Indeed, Yap and Lam (2006) see a shift in the center of gravity of cargo from Japan to mainland China leading to intensified competition between primary load centers and those in close proximity: Hong Kong v. Shenzhen (and Yantian), Shanghai v. Ningbo, Qingdao v. Tianjin and Busan v. Gwangyang Bay. Reprising an earlier pattern in which Japanese ports lost their transshipments to Hong Kong, Kaohsiung and Busan the last two ports may lose their traffic to Chinese ports. Looking beyond China, the relative slot capacities of Japanese and Taiwanese ports are in sharp relative decline. Smaller countries in Asia, such as Vietnam are still discounted (Thai and Gewal, 2005).

The China boom will affect both North American and European ports. In North America cargoes expected to double between 2000 and 2020 with Los Angeles/Long Beach expected to quadruple and New York/New Jersey triple their throughput over the same period (USDOT, 2005). These forecasts raise the specter of capacity congestion and inefficiencies in North America's intermodal system, particularly as Singapore will have more container capacity than the United States by 2010 (Maloni and Jackson, 2005). ${ }^{15}$ Besides the China effect, Europe's northern ports, particularly Hamburg, are likely to benefit from the European Union's expansion centered on freight corridors (ESPO, 2005). Some ports in the Hamburg to Le Havre range are likely to: intensify their competition with counterparts in the United Kingdom for transshipments; experience greater rivalry with Mediterranean offshore hubs; lose some cargo to new terminal initiatives in their vicinity; lose direct calls with consolidation of the container handling industry; and experience competition from small niche ports. There is also the possibility that some of the logistics activities associated with the regionalization phase's networks will be recast with the prospect of using lower-cost locations in Eastern Europe and Asia (Euro-CASE, 2001).

Looking ahead, will there be a China-style boom elsewhere in the world? Although forecasting is a notoriously difficult task, Goldman Sachs (2003) suggests that Brazil, India and Russia, are favored as the main foci of future long-term growth that will have a spin-off on containers (Table 7). ${ }^{16}$ Reference to Brazil is important, as more attention will need to be paid to the Southern Hemisphere. Already, Toyota, the multinational automobile maker, has established plants

\footnotetext{
${ }^{15}$ The port of Singapore's expansion is expected to raise capacity by 18 million TEUs to 35 million TEUs in 2009 (USDOT, 2005).

${ }^{16}$ UNESCAP (2001) provides information on structural changes in trade patterns to 2011.
} 
in South America and South America. India's ports remain an enigma in terms of container throughput though, sensing the prospects of accelerated growth, specialized firms have entered the market to operate port services (Jose, 2005). Russia may become more integrated with the European Union reviving its dormant prospects of becoming a transit hub in Eurasia, particularly if the Trans-Korean Railway is completed. Thus in the longer-term the three countries, in varying degrees, could be experiencing not only marked growth but also the decentralization of some activities.

Table 7

Container throughput in Brazil, Russia, India and China (the BRIC countries), at various dates between 1985 and 2004

\begin{tabular}{l|c|c|c|c|c|c|c}
\hline & 1985 & 1990 & 1995 & 2000 & 2001 & 2002 & 2004 \\
\hline \hline Brazil & 592 & 623 & 1,429 & 2,341 & 2,616 & 2,933 & 5059 \\
India & 382 & 687 & 1,383 & 2,314 & 2,591 & 3,242 & 4,267 \\
Russia & n.a. & n.a. & n.a. & n.a. & 382 & 796 & 1,368 \\
China & 2,736 & 16,303 & 17,229 & 35,483 & 43,970 & 55,717 & 74,540 \\
\hline
\end{tabular}

Note: Hong Kong figures for 1985 (2,289) and $1990(5,100)$ have been added to China.

Source: CI (1970-2005)

\section{Conclusions}

This study has been concerned with past patterns of inter-port competition, current conditions and possible future directions. If we are to come terms with comprehending the global productiondistribution networks built upon logistics there is need to go further than inter-port competition and explore the synergies between the supply chain and the total transport network. Indeed, seaports exhibit the same underlying hub and spoke structure as air transport and telecommunications.

The wider focus will concentrate our attention upon the way in which global production systems are underpinned by: (a) the flows of goods, people and information; (b) sea-land, air and communications modes; (c) port, airport and teleport nodes (i.e. gateways); and (d) the way in which they are bound together in the 'network of networks'. Already, there are indications that models devised for seaports are portable to air transport and telecommunications (Min and Guo, 2005). This search for synergies should lead to deeper consideration of the underlying differences between moving goods and people, and knowledge and information.

\section{Acknowledgement}

Dr. Sue Rimmer is thanked for providing fugitive material. 


\section{References}

Baird. A.J. 2006. Optimising the container transshipment hub location in northern Europe. Journal of Transport Geography, 14(3): 195-214.

Barzadukas D., J. Devore, H. Gamble, and J. Kopp. 2000. Competition and cooperation and trade policy: Past lessons and future opportunities for the Port of Tacoma and the Port of Seattle. University of Washington Global Trade, Transportation and Logistics Studies GTTL 502.

http:/depts.washington.edu/gttl/StudentPapersAbstracts/2000/port.competition.trade.p olicy.pdf

Bichou, K., and R. Gray. 2004. A logistics and supply chain management approach to port performance measurement. Maritime Policy and Management, 31(1): 47-67.

Bird, J.H. 1963. The Major seaports of the United Kingdom, London: Hutchison.

Bird, J.H. 1967. Seaport gateways of australia, London: Oxford University Press.

Bird, J.H. 1971. Seaports and seaport terminals, London: Hutchison.

Cheung, R., J. Tong, and B. Slack. 2003. The transition from freight consolidation to logistics: The case of Hong Kong. Journal of Transport Geography, 11: 245-253.

CI, 1970-2006. Containerisation international yearbook. London: Informa.

Defilippi, E. 2004. Intra-port competition, regulatory changes and the concession of Callao port. Maritime Economics and Logistics, 6(4): 279-311.

De Langen, P.W., and A. A. Pallis. 2005. Analysis of the benefits of intra-port competition, EconWPA. Search http://www.econowpa.wustl.edu/eprints/io/papers/0510/05/0510003

Delattre, A.J. 2005. Viewpoint: West Coast port congestion: Serious problem or significant opportunity for supply chain masters? http:/www.accenture.com/xdoc/en/ services/scm/ insights/ coast_port.pdf

De Souza Jr., G.A., A.K.C. Beresford, and J. Pettit. 2003. Liner shipping companies and terminal operators: Internationalisation or globalisation. Maritime Economics and Logistics, 5(4): 393-412.

Dick, H.W., and P. J. Rimmer. 1993. The Trans-Pacific economy: A network approach to spatial structure. Asian Geographer, 12 (1\&2): 5-9.

Dick. H.W., and P. J. Rimmer. 2003. Cities, transport and communications: The integration of Southeast Asia since 1850. London: Palgrave MacMillan.

Euro-CASE. 2000. Freight logistics and transport systems in Europe: Trends in the location of European industry and its interaction with logistics and transport. European Council of Applied Science and Engineering.

http://www.euro-case.org/Activities/Freight_FinalReport.pdf

ESPO. 2004-05. Factual report on the European port sector: 1 factual report - work package 1(FRWP1), Brussels, European Seaports Organisation (prepared by T. Notteboom and W. Winkelmans).

http://www.espo.be/publications/ Factual\%20Report\%20for\%20Web.pdf 
Goldman Sachs. 2003. Dreaming with the BRICs: The path to 2050 (by Dominic Wilson and Roopa Prushothaman). Global Economics Paper, No. 99.

Goss, R.O., 1990. Economic policies and seaports: 1. The economic function of seaports. Maritime Policy and Management, 17(3): 207-219.

Hall. P.V. 2003. Territorial strategies of seaport authorities: Ideas for a research project. http://ww.stellaproject.org/FocusGroup5/SantaBarbara2003/Short\%20presentations/P eter\%20Hallseaport.pdf

Haynes, K.E., Y. H. Hsing, and R. R. Stough. 1997. Regional port dynamics in the global economy: The case of Kaohsiung, Taiwan. Maritime Policy and Management, 24: 93113.

Hayuth, Y. 1988. Nationalization and deconcentration of the U.S. container port system. The Professional Geographer, 40: 279-288.

Hensel, B. 2004. Port of Houston compete with California for Asian trade. http://bloghouston.net/item/29

Hoyle, B.S. 1967. East African seaports: An application of the concept of Anyport. The Institute of British Geographers, Transactions. XX: 163-83.

Hoyle, B.S. 1989. The port-city interface: Trends problems and examples. Geoforum, 20: 429-35

Hoyle, B., and R. Knowles. 1992. Transport geography: An introduction. B. Hoyle and R. Knowles. Modern transport geography: 1-10. London: Belhaven Press.

Jose, P. 2005. India and the global container ports. Maritime Economics and Logistics, 7(2): 189192.

Lai, K.H., T.C.E. Cheng, and A.C.L. Yeung. 2004. An empirical taxonomy for logistics service providers. Maritime Economics and Logistics, 6(3): 199-219.

Lee, J.Y., and J-P. Rodrique. 2006. Trade reorientation and its effects on regional port systems: The Korea-China link along the Yellow Sea Rim. Growth and Change, 37(4): 597619.

Maloni, M. and E.C. Jackson. 2005. North American container capacity: A literature review. Transportation Journal, 44(2): 16-36.

McCalla, R.J. 2004 From 'Anyport' to 'Superterminal., D. Pinder and B. Slack. eds. Shipping an Ports in the Twenty-first Century: 123-142. London: Routledge.

McCalla, R.J., B. Slack, and C. Comtois. 2004. Dealing with globalisation at the regional and local level: The case of contemporary containerization. Canadian Geographer, 48(4): 473487.

Min H., and Z. Guo. 2004. The location of hub-seaports in the global supply chain network using a cooperative competition strategy. International Journal of Supply Chain Management, 1(1): 51-63.

Monie, G.D. 1987. Measuring and evaluating port performance and productivity. UNCTAD Monographs on Port Management No. 6, 2-11. Tokyo: International Association of Ports and Harbors.

Mourao, M.C., M.V. Pato, and A.V. Paixao. 2001. Ship assignment with hub and spoke constraints. Maritime Policy Management, 29(2): 135-150.

Ng K.Y.U. 2004. Competition of North Europe: A case study on the implications of shipping lines. 
Strategies \& Port Choices on Port of Rotterdam's Container Transshipment Market, TransportSudies Unit,Oxford University. http://www.tsu.ox.ac.uk/seminars /mt04?s_tsu07.ppt

Notteboom, T.F. 2004. Container shipping and ports: An overview. Review of Network Economics, 3(1): 86-106.

Notteboom, T.F. 2005. Is more port competition needed? Paper presented at the second EU Ports Package: The good or the last try? May 20. Antwerp. www.espo.be/news/2005/events/EUR\%20INS\%20PP2\%20prog\%20short.pdf.

Notteboom, T.F., and J-P. Rodrique. 2005. Port regionalization: Towards a new phase in port development. Maritime Policy and Management, 32(3): 297-313.

Notteboom, T.F., and W. Winkelmans. 2001. Structural changes in logistics: How will port authorities face the challenge. Maritime Policy and Management, 28(1): 71-89.

OECD. 2004. OECD Territorial Reviews: Busan, Korea, Paris: OECD http://213.253.134.29/oecd/pdfs/browseit/0405021E.PDF

OSC. 2005. The proposed directive on market access to port services and container terminal operations in Northern Europe: A critical review. May 2005. London: Ocean Shipping Consultants Ltd. http://www.maritimelondon.com/london_matters/17june05.shtml - 48k.

Podevins, O. 2005. Inland waterway terminals as strategic interfaces on intermodal transport chains in Central Europe. Paper presented at the Conference on International Trader and Logistics, Corporate Strategies and the Global Economy - European and East Asian Perspectives, 25-28 September 2005. Le Havre.

Rimmer, P.J. 1965. New Zealand seaports. Unpublished Ph. D thesis in Geography, University of Christchurch, New Zealand.

Rimmer, P.J. 1967a. The changing status of New Zealand seaports, 1853-1960. Annals of the Association of American Geographers, 57: 88-100.

Rimmer, P.J. 1967b. The search for spatial regularities among Australian seaports. Geografiska Annaler, 49, Ser. B:42-54.

Rimmer, P.J. 1997. Shipping patterns in the Western Pacific - the China factor. Maritime Studies, No. 94: 1-27.

Rimmer, P.J. 1998. Impact of global shipping alliances on Pacific Rim ports. Maritime Studies, No. 98: $1-28$.

Rimmer, P.J. 2002. Global transport: Australia as a cul-de-sac. C. Shiel. ed. Australia and Globalisation, 35-57. Sydney: UNSW Press.

Rimmer P.J. 2004. Manga world: Globalization theory revisited. Jimbun Chiri [Human Geography], 56(6): 7-28.

Rimmer, P.J., and Y.T. Chang. 2005. New roles for Incheon's Port Authority: Precedents, perspectives and policies. Korea Observer, 36(2): 297-322.

Robinson, R. 1998. Asian hubs/feeder nets: The dynamics of restructuring. Maritime Policy and Management, 25(1): 21-24.

Robinson, R. 2002. Ports as elements in value-driven chain systems: The new paradigm. Maritime Policy and Management, 29(3): 241-255. 
Rodrique, J-P. 2004. Freight gateways and mega-urban regions: The logistical integration of the Bostwash Corridor. Tidjschrift voor Economicshe en Sociale Geografie, 95(2): 147161.

Rodrique, J-P., and M. Hesse. forthcoming. Globalized trade and logistics: North America perspectives. T. Leinbach and C. Capineri. eds. Globalized freight, transport economics. Management and Policy series. Cheltenham, UK: Edgar Elgar Publishing.

SET. 2002. Container transshipment and demand for container terminal capacity in Scotland, Scottish Executive Transport. http://www.scoltand.gov.uk/library5/transoprt/ctdctc08.asp

Slack B. 1999. Shipping lines and their influence on port development. The Dock and Harbour Authority, 79 (894): 249-250.

Slack, B., C. Comtois, and R. McCalla. 2002. Strategic alliances in the container shipping industry: A global perspective. Maritime Policy and Management, 29: 65-76.

Slack, B., and A. Frémont. 2005. Transformation of port terminal operations: From the local to the global. Transport Reviews, 23(1): 117-130.

Slack B., and J. Wang. 2002. The challenge of peripheral ports: An Asian perspective. GeoJournal, 56: 159-166.

Song, D.W. 2002. Regional port competition and co-operation: The case of Hong Kong and South China. Journal of Transport Geography, 10: 99-110.

Song, D.W., and K.T. Yeo. 2004. A competitive analysis of Chinese container ports using the analytic hierarchy process. Maritime Economics and Logistics, 6(1): 34-52.

Taaffe, E. J., R. L. Morrill, and P. R. Gould. 1963. Transport expansion in underdeveloped countries: A comparative analysis. Geographical Review, 53: 503-529.

Thai, V.V., and D. Grewal. 2005. An analysis of the efficiency and competitiveness of Vietnamese port system. Asia Pacific Journal of Marketing and Logistics, 17(1): 3-32.

Tiwari, P, H. Itoh, and M. Doi. 2003. Shippers' port and carrier selection behaviour in China: A discrete choice analysis. Maritime Economics and Logistics, 5(1): 23-39.

Tongzon, J., and H. Wu. 2005. Port privatisation, efficiency and competitiveness: Some empirical evidence from container ports (terminals). Transportation Record A: Policy and Practice, 39(5): 405-424.

USDOT. 2005. Report to Congress on the performance of ports in the intermodal system. U.S. Department of Transportation Maritime Administration.

http://www.marad.dot.gov/.../Report\%20to\%20CongressPorts\%20\%20Intermodal\%2 0Efficiency\%206-21-05\%20final.pdf.

UNESCAP. 2001. Maritime Policy Model (MPPM): Regional shipping and port development strategies under a changing maritime environment. UNESCAP Reference no. ST/ESCAP/2153, Transport and Tourism Division. http://www.unescap.org/publications/detail.asp?id=455

Veldman, S.J., and E. W. Buckmann. 2003. A model on container port-competition: An application for the West European container hub-ports. Maritime Economics and Logistics, 5(1): 3-19.

Wang J., and B. Slack. 2000. The evolution of a regional container port system: The Pearl River 
Delta: Journal of Transport Geography, 8: 263-276.

Yamada, H. 1997. Supply-side economics and its mechanism - The reality of the ocean shipping economy. Paper presented at the International Symposium on Liner Shipping, Hamburg, 21-23 April, p.7.

Yap W.J., and J.S.L. Lam. 2006. Competition dynamics between container ports in East Asia. Transportation Research Part A: Policy and Practice, 40(1): 35-51. 